\title{
Studies on the Apolipoproteins and Lipoproteins of Cord Serum
}

\author{
WALTER J. McCONATHY ${ }^{(53)}$ AND DANIEL M. LANE \\ Laboratory of Lipid and Lipoprotein Studies, Oklahoma Medical Research Foundation and The Oklahoma City \\ Clinic, Oklahoma City, Oklahoma, USA
}

\begin{abstract}
Summary
Studies on the cord serum lipid transport system were initiated to determine whether there is a correlation between decreased cord serum lipid levels and the absence or diminished level of some or all of the human serum apolipoproteins. Immunologic studies indicated the presence of all the well-characterized apolipoproteins and provided evidence that these apolipoproteins occurred primarily as distinct lipoprotein species with a paucity of association complexes or what others have termed "triglyceride-rich" lipoproteins. Quantitation of the apolipoproteins present in cord serum by electroimmunoassay yielded the following mean levels: $\mathrm{A}-\mathrm{I}=$ $730 \mathrm{mg} /$ liter; A-II $=410 \mathrm{mg} /$ liter; apolipoprotein B $=280 \mathrm{mg} /$ liter; C-I $=59 \mathrm{mg} /$ liter; C-II $=32 \mathrm{mg} /$ liter; C-III $=65 \mathrm{mg} / \mathrm{liter}$; apolipoprotein $D=37 \mathrm{mg} / \mathrm{liter}$; and apolipoprotein $E=85 \mathrm{mg} /$ liter. Levels of C-I, C-II, and apolipoprotein $E$ approached adult levels ( 83 to $86 \%$ of the adult levels), whereas apolipoproteins $B$ and $D$ were most reduced when compared to the adult concentrations, 29 and $37 \%$, respectively. The three other apolipoproteins were present at approximately one-half the levels found in adults.
\end{abstract}

\section{Speculation}

The immunochemical studies on the apolipoprotein levels and lipoprotein forms of cord serum provide part of the data necessary for studying the progressive changes in the human lipid transport system from its fetal form to that of the adult.

Studies on the human adult serum lipid transport system have established that the major serum lipids (triacylglycerol, cholesterol, cholesteryl esters, and phospholipids) are bound to particular protein constituents $(14,32)$, designated apolipoproteins. Such lipid-protein complexes (lipoproteins) have been most commonly classified on the basis of two of their characteristic physical properties, i.e., hydrated density (26) and charge (30).

Studies on the antigenic components of the major lipoprotein density classes and electrophoretic bands in the human adult have clearly demonstrated their protein heterogeneity $(4,37)$ and lead to a classification system based on apolipoproteins as the only distinct chemical markers of this system $(1,2)$. This concept has been developed into the lipoprotein family theory and has been described elsewhere (2). Recently, the levels of all well-recognized apolipoproteins have been reported (3).

Application of these physicochemical techniques to cord sera has established that compared to normal adult levels, very low density lipoprotein (VLDL) is virtually absent (39) or present in low concentrations $(13,15)$, low-density lipoprotein (LDL) is markedly decreased $(8,42)$, and the predominant lipoprotein density class is high-density lipoprotein (49). In addition, the lipid levels of cord sera are also lower than the corresponding levels in adult sera $(42,49,50)$. However, it has not been established whether there is a correlation between the decreased cord serum lipid levels $(42,49,50)$ and the absence or diminished level of some or all of the apolipoproteins. The studies described herein are the first reports of the qualitative and quantitative composition of the apolipoproteins and their lipoprotein forms in human cord serum.

\section{MATERIALS AND METHODS}

Cord blood was collected from the placental end of the umbilical vein following transection at delivery. Serum was collected by low-speed centrifugation and stored at $4^{\circ} \mathrm{C}$ in the presence of $0.01 \%$ thimerosal, $0.01 \%$ of $\mathrm{NaN}_{3}$, and ethylenediaminetetraacetic acid, tetrasodium salt dihydrate (EDTA) until analytical studies were begun. Cord sera from infants of birth weight $<2500 \mathrm{~g}$ with an estimated gestational age of less than 38 wk or greater than 42 wk and with any known perinatal problems were not included in any of the studies on normal cord sera.

Triacylglycerol and total cholesterol were determined according to the procedures recommended by the Lipid Research Clinics (31), whereas free cholesterol and lipid phosphorous were assayed by previously described procedures (5). Lipid phosphorous was converted to phospholipid by the factor 25 . Serum-free fatty acids were extracted (29), and their levels were determined by gas-liquid chromatography as described by Mason and Waller (34). Serum lipids were determined within two wk of collection.

Double-diffusion and immunoelectrophoretic analyses were performed in $1 \%$ agarose as described earlier (4). These analyses were done within 3 to 4 days after collection. The preparation of antisera to A-I, A-II, lipoprotein B (LP-B), C-I, C-II, C-III, apolipoprotein $\mathrm{D}(\mathrm{ApoD})$, and apolipoprotein $\mathrm{E}(\mathrm{ApoE})$ for these analyses has been described in other reports $(4,16)$. Quantification of these apolipoproteins was performed by adaptation of Laurell's rocket electrophoresis as described in several reports from this laboratory $(3,16-19)$. Serum samples for apolipoprotein quantification were either analyzed immediately or stored at $-20^{\circ} \mathrm{C}$ until analyses were performed. Under these conditions, storage had no effect on the stability of lipids and apolipoproteins.

\section{RESULTS}

Double-diffusion analyses of cord sera demonstrated the presence of all well-characterized adult apolipoproteins (Fig. 1), and these patterns were typical for all cord sera tested. The reactions of nonidentity between the antisera to LP-B, ApoE, ApoD, and A-II have been interpreted to indicate that these apolipoproteins reside on different lipoprotein species. The spur, indicated partial identity (38) between anti-A-I and anti-A-II, suggests the presence of two species of A-I-containing lipoproteins; one of these designated lipoprotein A (LP-A) contains both A-I and A-II, whereas the other contains only A-I and probably corresponds to LP-A-I found in the adult system. These two lipoprotein forms of A-I have been previously reported for the human adult system $(6,48)$. The reaction of identity between antisera to C-I, C-II, and C-III when tested against cord serum indicates the presence of a lipoprotein species containing C-I, C-II, and C-III polypeptides. 


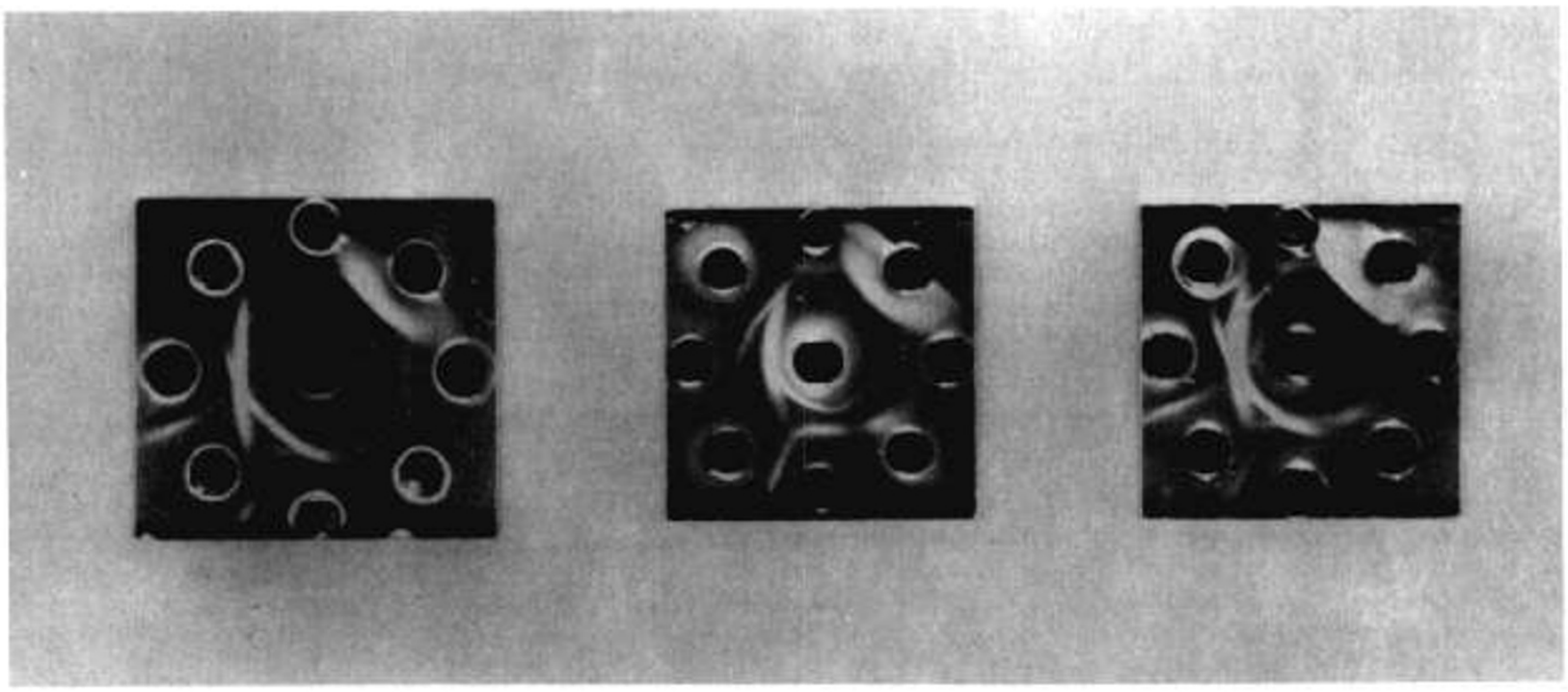

Fig. 1. Double diffusion analyses of three different cord sera in $1 \%$ agarose. Cord serum in the center wells, outer wells from the top. clockwise, contain antibodies to A-II, A-I, C-III, C-II, C-I, LP-B, ApoE, and LP-D.

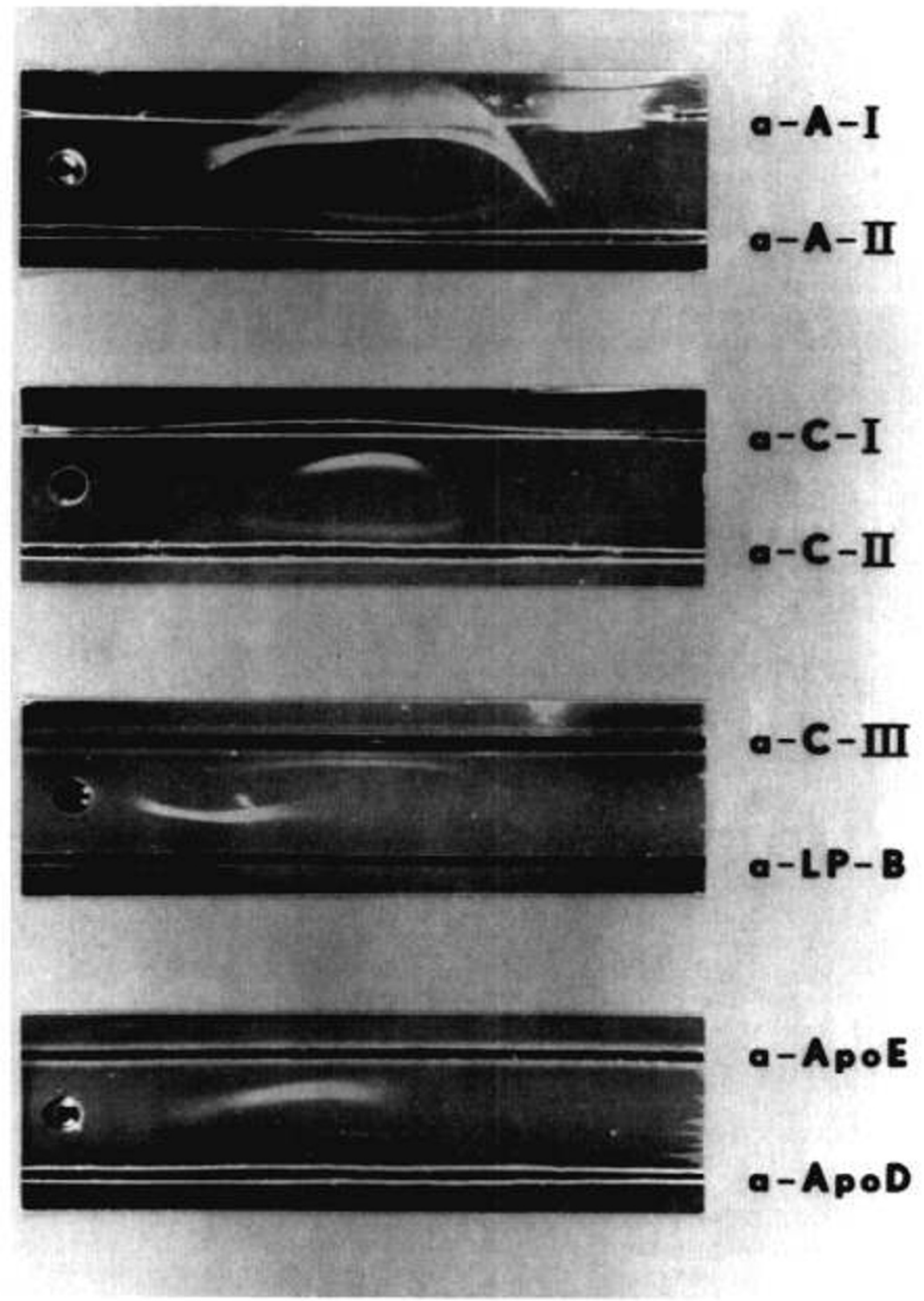

Fig. 2. Immunoelectrophoretic analysis of cord serum in $1 \%$ agarose. 
Results of the double-diffusion experiments were supported by the immunoelectrophoretic analyses of cord serum (Fig. 2). Mobilities of the precipitin arcs observed with anti-A-I and anti-A-II were similar, suggesting the presence of a lipoprotein species containing A-I and A-II, specifically LP-A. Even though C-I and C-III when analyzed by immunoelectrophoresis have different mobilities in their lipid-free form in agar (11) and agarose, the cord serum yielded precipitin arcs to anti-C-I, C-II, and C-III of similar mobilities, supporting the double-diffusion analyses which indicated the presence of lipoprotein C (LP-C). Precipitin arcs with antiserum to LP-B, ApoE, and ApoD had mobilities dissimilar to LP-A, LP-C, and each other. The only exception was the similar mobilities of lipoprotein D and LP-C. The immunoelectrophoretic and double diffusion patterns are compatible with at least six lipoprotein species: LP-A, LP-A-I, LP-B, LP-C, lipoprotein $D$, and lipoprotein $E$. The major difference as judged by immunochemical techniques between the adult and fetal lipid transport systems with respect to the forms of lipoproteins is the absence or extremely low levels in the fetal system of what we have termed association complexes $(2,18)$ and others have referred to as "triglyceride-rich" lipoproteins (37). These.association complexes characterized by the fusion of precipitin arcs between antisera to LP-B, C-I, and/or ApoE (Fig. 3) were not detected in cord serum (Fig. 2). The free form of LP-C in both adult and cord serum had similar mobilities (Fig. 3). This suggests that lipoprotein species containing various combinations of apolipoproteins B (ApoB), C, and E (association complexes) are markedly reduced in eord serum. Such a finding would be expected because lipoproteins with $S>20$ are virtually absent or present at low levels in the fetal system $(13,15,39)$ although they represent the primary localization of such association complexes in the adult (17).

Lipid and ApoB analyses of 255 normal cord sera (Table 1) agree with previous reports of low cord serum lipid and ApoB levels $(42,49,50)$. The total cholesterol:unesterified cholesterol ratio is similar to the adult ratio, indicating that the enzyme responsible for esterification of cholesterol, lecithin:cholesterol acyltransferase is functioning adequately in cord sera to maintain the ratio of cholesterol esters and cholesterol at levels similar to the adult ratio or that in the fetal system a large portion of the cholesteryl esters stem from the liver. Free fatty acids of cord sera (Table 2) were lower $(20,40)$ and represented about one-third the levels of adult serum. Compositionally, the fatty acids contained relatively more saturated fatty acids $(20,40)$, particularly palmitic acid.

Lipid levels of cord serum from males and females indicated higher triacylglycerol levels in males, lower total and free cholesterol levels, and lower phospholipid levels than those seen in females (Table 3 ). Only the total cholesterol levels of males and females were significantly different $(P<0.05)$. The lower levels of cholesterol in males agree with studies on sex differences in cord sera at birth $(9,10)$.

Quantitation of apolipoprotein levels (Table 4) confirmed the double diffusion analyses indicating the presence of all wellcharacterized adult apolipoproteins. ApoB levels were the most reduced when compared to adult levels in agreement with other reports $(7,23)$, whereas apoproteins A-I, A-II, C-III, and ApoD were 37 to $60 \%$ of the corresponding adult levels. The amounts of C-I, C-II, and ApoE were present at levels approaching those of the normal adult (3). Comparison of adult and cord apolipoprotein levels in both $\mathrm{mg}$ and $\mu$ mole/liter, as well as ratios of A-I:A-II and C-I:C-II:C-III indicate similarities in the ratios of A-I:A-II (adult, 1.22 versus cord, 1.08) whereas the C-I:C-II:C-III (adult, 2.5:1.0:3.2 versus cord, 2.5:1.0:1.9) ratio is somewhat different due principally to the decreased C-III level.

Table 2. Free fatty acid levels in cord and adult serum

\begin{tabular}{lccrr}
\multicolumn{1}{c}{$\begin{array}{c}\text { Fatty } \\
\text { acid }\end{array}$} & $\begin{array}{c}\text { Cord } \\
(n=21) \\
(\mu \text { mole/liter })\end{array}$ & $\begin{array}{c}\text { Adult } \\
(n=7) \\
(\mu \text { mole/liter })\end{array}$ & $\begin{array}{c}\text { Cord } \\
(w t \%)\end{array}$ & $\begin{array}{r}\text { Adult } \\
(w t \%)\end{array}$ \\
\hline Myristic & $3.3 \pm 0.8^{1}$ & $9.9 \pm 1.3$ & 1.8 & 2.0 \\
Palmitic & $81.5 \pm 8.4$ & $138 \pm 17.7$ & 46.8 & 29.8 \\
Palmitoleic & $3.5 \pm 1.3$ & $11.8 \pm 3.2$ & 2.0 & 2.5 \\
Stearic & $19.3 \pm 3.1$ & $30.9 \pm 2.4$ & 12.3 & 7.4 \\
Oleic & $44.6 \pm 7.7$ & $156 \pm 21.9$ & 28.2 & 37.1 \\
Linoleic & $14.3 \pm 3.9$ & $85.2 \pm 8.6$ & 8.9 & 20.1 \\
Linolenic & $\mathrm{ND}^{2}$ & $4.7 \pm 1.2$ & $\mathrm{ND}$ & 1.1 \\
& & & & \\
Total & 166.5 & 436.5 & & \\
\hline
\end{tabular}

${ }^{1}$ Mean \pm S.E.

${ }^{2}$ ND, not detected.

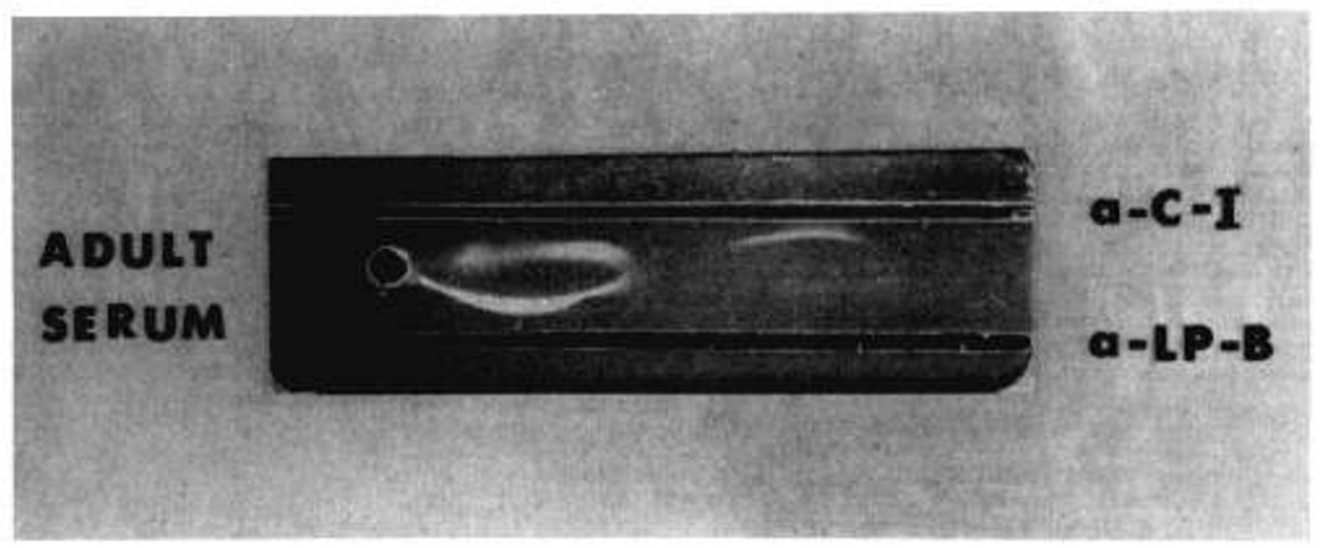

Fig. 3. Immunoelectrophoretic analysis of adult serum in 1\% agarose.

Table 1. Lipid and ApoB levels in cord serum of normal infants ${ }^{1}$

\begin{tabular}{|c|c|c|c|c|c|c|}
\hline & $\begin{array}{l}\text { Wt } \\
(\mathrm{kg})\end{array}$ & $\begin{array}{c}\text { Triacylglycerol } \\
\text { (mg/liter) }\end{array}$ & $\begin{array}{c}\text { Total } \\
\text { cholesterol } \\
\text { (mg/liter) }\end{array}$ & $\begin{array}{c}\text { Unesterified } \\
\text { cholesterol } \\
\text { (mg/liter) }\end{array}$ & $\begin{array}{c}\text { Phospholipid } \\
\text { (mg/liter) }\end{array}$ & $\begin{array}{c}\text { ApoB } \\
\text { (mg/liter) }\end{array}$ \\
\hline $\begin{array}{l}\text { Mean } \pm \text { S.E. } \\
\text { Range }\end{array}$ & $3.48 \pm 0.03$ & $\begin{array}{l}435 \pm 11 \\
170-1140\end{array}$ & $\begin{array}{l}713 \pm 11 \\
350-1560\end{array}$ & $\begin{array}{l}168 \pm 4 \\
60-350\end{array}$ & $\begin{array}{l}1250 \pm 23 \\
330-2420\end{array}$ & $\begin{array}{l}289 \pm 6 \\
100-570\end{array}$ \\
\hline
\end{tabular}

\footnotetext{
${ }^{\prime} n=255$.
} 
Table 3. Comparison of cord serum lipid levels of males and females ${ }^{1}$

\begin{tabular}{lccccc}
\hline \multicolumn{1}{c}{ Sex } & $\begin{array}{c}\mathrm{Wt} \\
(\mathrm{kg})\end{array}$ & $\begin{array}{c}\text { Triacylglycerol } \\
(\mathrm{mg} / \mathrm{liter})\end{array}$ & $\begin{array}{c}\text { Total } \\
\text { cholesterol } \\
(\mathrm{mg} / \mathrm{liter})\end{array}$ & $\begin{array}{c}\text { Free } \\
\text { cholesterol } \\
(\mathrm{mg} / \text { /liter })\end{array}$ & $\begin{array}{c}\text { Phospholipid } \\
(\mathrm{mg} / \mathrm{liter})\end{array}$ \\
\hline Male $(n=104)$ & $3.32 \pm 0.06^{3}$ & $454 \pm 25.4$ & $690 \pm 15.3$ & $157 \pm 4.9$ & $1165 \pm 22.7$ \\
Female $(n=112)$ & $3.20 \pm 0.06$ & $433 \pm 18.0$ & $750 \pm 16.0$ & $160 \pm 4.5$ & $1222 \pm 21.9$ \\
\hline
\end{tabular}

' Consecutive cord serum samples.

${ }^{2}$ Significantly different $(P<0.05)$.

${ }^{3}$ Mean \pm S.E.

Table 4. Human apolipoprotein levels in cord and adult serum determined by electroimmunoassay

\begin{tabular}{|c|c|c|c|c|c|c|}
\hline Apolipoprotein & $(n)$ & $\begin{array}{c}\text { Cord } \\
\text { (mg/liter) }\end{array}$ & $\begin{array}{c}\text { Adult' } \\
\text { (mg/liter) }\end{array}$ & $\begin{array}{c}\text { Cord } \\
(\mu \text { moles/liter }) \\
\end{array}$ & $\begin{array}{c}\text { Adult } \\
(\mu \text { moles/liter })\end{array}$ & $\begin{array}{c}\text { Cord:adult } \\
(\mu \mathrm{moles} / \text { liter })\end{array}$ \\
\hline A-I & 171 & $730 \pm 15^{2}$ & $1340 \pm 34$ & 26.1 & 47.8 & 0.54 \\
\hline A-II & 152 & $410 \pm 10$ & $680 \pm 25$ & 24.1 & 39.1 & 0.60 \\
\hline ApoB & 198 & $280 \pm 6$ & $980 \pm 28$ & 1.1 & 3.9 & 0.29 \\
\hline$C-I$ & 96 & $59 \pm 2$ & $70 \pm 3$ & 8.9 & 10.6 & 0.84 \\
\hline C-II & 97 & $32 \pm 3$ & $37 \pm 3$ & 3.6 & 4.2 & 0.86 \\
\hline C-III & 165 & $65 \pm 2$ & $130 \pm 7$ & 6.8 & 13.6 & 0.50 \\
\hline ApoD & 155 & $37 \pm 1$ & $100 \pm 6$ & 1.7 & 4.5 & 0.37 \\
\hline ApoE & 187 & $83 \pm 3$ & $100 \pm 6$ & 2.6 & 3.1 & 0.83 \\
\hline
\end{tabular}

' Ref. 3.

${ }^{2}$ Mean \pm S.E.

\section{DISCUSSION}

Im munochemical studies of the cord lipid transport system have shown that all the well-characterized apolipoproteins are present although at lower levels than found in the normal adult, indicating that the reduced levels of cord serum lipids are not associated with an absence of any of the well-characterized apolipoproteins but rather with a reduction in the levels of each of them to different extents. ApoB, ApoD, and C-III were the most reduced of the apolipoproteins as were cholesterol esters and fatty acids of cord serum lipids.

C-I, C-II, and ApoE are present at levels approaching those found in the adult. All of these have been shown to be involved in lipolytic processes, C-II as a cofactor for lipoprotein lipase (27), C-I as a cofactor for lecithin:cholesterol acyltransferase (46), and ApoE as an inhibitor of lipoprotein lipase (41). In addition, ApoE has been shown to be increased in cholesterol-fed animals (43) and has an affinity for receptors found in peripheral membranes (33).

Because C-I, C-II, and ApoE are present at levels approaching those seen in the adult, these three apolipoproteins would appear to play important roles in the delivery or storage of lipids in tissues of the rapidly growing fetus, either as cofactors for lipolytic enzymes or as lipid shuttles between various serum lipoprotein species or cellular membranes. Their role in storage of lipids in various fat depots would appear to be of importance because the energy needs of the growing fetus are primarily met by carbohydrate metabolism (21), whereas fat metabolism becomes more important shortly after birth (35).

In addition to the reduced levels of some of the apolipoproteins, the fetal lipid transport system appears to contain lipoprotein families $(2,3)$ that occur mainly in their free form and $n t$ together with one another in association complexes. The abserice or extremely low levels of association complexes or what others have termed triglyceride-rich lipoproteins (37) correlates with the reduced levels of plasma triacylglycerol and $\operatorname{VLDL}(39,50)$. The low amounts of association complexes strongly suggest that an insignificant amount, if any, of intact VLDL or other lipoproteins from the mother cross the placenta in agreement with other investigators $(9,10,21,23,25,50)$. This conclusion is supported by evidence indicating that of the lipid moieties in maternal serum only free fatty acids $(20)$ and unesterified cholesterol $(10,28)$ are transferred across the placental membranes at term. Whether the low levels of association complexes and LP-B are related to one another or are related to the virtual absence of gastrointestinal absorption of exogenous fat (44), to the rapid utilization of triacylglycerol and cholesterol by various organs for storage of energy and formation of membranes, to the hormonal effects such as estrogen $(24,45)$, or to other variables is not clear. The utilization of triacylglycerol for storage is possibly reflected also by the lowserum free fatty acid levels.

An interesting comparative aspect of this study was that the fetal lipid transport system is similar in its lipoprotein density class distribution $(8,49)$ to that of other animal systems (36). Most other mammalian systems including a number of nonhuman primates $(36,47)$ are characterized by relatively low LDL levels and high high-density lipoprotein levels. At some time after birth, the human lipid transport system is transformed from one containing relatively low VLDL and LDL levels to the adult system with a relatively high LDL level (36), which continues to increase with age (22). The initial changes in the lipid transport system probably result from the initiation of $\mathrm{PO}$ feedings with milk (human or otherwise) and the end of hormonal effects contributed by the mother and placenta. Thereafter, the substantial energy needs of the rapidly growing infant must require a very efficient and effective system for transporting ingested lipids to various tissues. Until the infant's growth rate falls to that of a young child, the energy requirements for rapid growth would be expected to determine the nature of the lipid transport system. When a stable growth rate has been achieved, the system should then reflect the dynamic nature of lipid metabolism required for meeting the maintenance energy needs of man. The data on apolipoproteins presented here can serve as a starting place for study of the lipid transport system as it changes during the early days and months of life.

\section{REFERENCES AND NOTES}

1. Alaupovic, P.: Recent advances in metabolism of plasma lipoproteins: chemical aspects. Prog. Biochem. Pharmacol.. 4: 91 (1968)

2. Alaupovic, P.: Conceptual development of the classification systems of plasma lipoproteins. Protides Biol. Fluids Proc. Collog. Bruges, 19: 9 (1972).

3. Alaupovic, P., Curry, M. D., and McConathy, W. J.: Quantitative determination of human plasma apolipoproteins by electroimmunoassays. In: L. A. Carlson, R. Paoletti. C. R. Sirtori: International Conference on Atherosclerosis. p. 109 (Raven Press, New York. 1978).

4. Alaupovic, P., Lee, D. M., and McConathy, W. J.: Distribution of lipoprotein families in major density classes of normal human plasma lipoproteins. Biochim. Biophys. Acta, 260: 689 (1972). 
5. Alaupovic, P., Sanbar, S. S., Furman, R. H., Sullivan, M. L., and Walraven, S $\mathrm{L}$.: Isolation and characterization of very high density lipoproteins of human serum. Biochemistry, S: 4044 (1966).

6. Albers, J. J., and Aladjem, F.: Precipitation of ${ }^{125}$ /-labeled lipoproteins with specific polypeptide antisera. Evidence for two populations with differing polypeptide compositions in human high density lipoproteins. Biochemistry. 10: 3436 (1971).

7. Andersen, G. E., and Nielsen, H. G.: Neonatal screening for hyperlipoproteinemia. Methods for direct estimation of cord serum VLDL + LDL. Clin. Chim Acta, 66: 29 (1976).

8. Auerswald, W., Doleschel, W., and Muller-Hartburg. W.: Flotationsanalytische Untersuchungen zur Frage der Anderung des Serum-lipoprotein Spektrum wahrend der ersten Lebenswoche, Klin Wochenschr., 4I: 580 (1963).

9. Barnes, K.. Nestel, P. J.. Pryke, E. S., and Whyte, H. M.: Neonatal plasma lipids. Med. J. Aust., 2: 1002 (1972).

10. Biezenski, J. J.: Fetal lipid metabolism, Obstet. Gynecol. Annu., 4: 39 (1975).

11. Brown, W. V., Levy, R. I., and Fredrickson. D. S.: Studies of the proteins in human plasma very low density lipoproteins. J. Biol. Chem., 244: 5687 (1969)

12. Carlson, L. A., and Hardell, L. I.: Sex differences in serum lipids and lipoprotein at birth. Eur. J. Clin. Invest., 7: 133 (1977).

13. Carlson, L. A., and Hardell, L. I.: Very low density lipoproteins in cord blood. Clin. Chim. Acta, 90: 295 (1978).

14. Cohn, E. J., Strong, L. E., Hughes, W. L., Jr., Mulford. D. J., Ashworth, J. N. Melin, M.. and Taylor, H. L.: Preparation and properties of serum and plasma proteins. IV. System for separation into fractions of protein and lipoprotein components of biological tissues and fluids. J. Am. Chem. Soc., 68: 459 (1946).

15. Cress, H. R., Shaher, R. M., Greenberg, M. H., and Laffin, R.: Lipoproteins in neonates. J. Pediatr., 84: 585 (1974).

16. Curry, M. D., Alaupovic, P., and Suenram, C. A.: Determination of apolipoprotein $A$ and its constitutive A-I and A-II polypeptides by separate electroim. munoassay. Clin. Chem., 22: 315 (1976)

17. Curry, M. D., Gustafson, A., Alaupovic, P., and McConathy, W. J.: Electroimmunoassay, radioimmunoassay, and radial immunodiffusion assay evaluated for quantification of human apolipoprotein B. Clin. Chem., 24: 280 (1978).

18. Curry, M. D., McConathy. W. J., and Alaupovic, P.: Quantitative determination of human apolipoprotein $D$ by electroimmunoassay and radial immunodiffusion. Biochim. Biophys. Acta, 491: 232 (1977).

19. Curry, M. D., McConathy, W. J., Alaupovic, P., Ledford, J. H., and Popovic, M. Determination of human apolipoprotein E by electroimmunoassay. Biochim. Biophys. Acta, 439: 413 (1976)

20. Elphick, M. C.. Hull, D., and Sanders, R. R.: Concentrations of free fatty acids in maternal and umbilical cord blood during elective caesarean section. $\mathrm{Br}$. J. Obstet. Gynaecol., 83: 539 (1976).

21. Fredrickson, D. S., and Breslow, J. L.: Primary hyperlipoproteinemia in infants. Annu. Rev. Med., 24: 315 (1973).

22. Fredrickson, D. S., Levy, R. 1.. and Lees, R. S.: Fat transport in lipoproteins-an integrated approach to mechanisms and disorders. N. Engl. J. Med., 276: 14 (1967).

23. Freis-Hansen, B., and Clausen, J.: Studies on serum lipoproteins in the neonatal period. Z Ernashrungswiss., 10: 253 (1971).

24. Furman, R. H., Alaupovic, P., and Howard, R. P.: Effects of androgens and estrogens on serum lipids and the composition and concentration of serum lipoproteins in normolipidemic and hyperlipidemic states. Biochem. Pharmacol., 2: 215 (1967)

25. Glueck, C. J., Heckman, F., Schoenfeld, M., Steiner, P., and Pearce, W.: Neonatal familial type II hyperlipoproteinemia: cord blood cholesterol in 1800 births. Metabolism. 20: 597 (1971).

26. Gofman, J. W., Lindgren, F. T., and Elliott, H.: Ultracentrifugal studies of lipoproteins of human serum. J. Biol. Chem., 179: 973 (1949).

27. Havel, R. J., Shore, V. G., Shore, B., and Bier, D. M.: Role of specific glycopeptides of human serum lipoproteins in the activation of lipoprotein lipase. Circ. Res., 47: 595 (1970).

28. Khamsi, F., Merkatz, I., and Solomon, S.: The conversion of acetate to cholesterol in the fetus of the baboon and the transfer of cholesterol from mother to fetus. Endocrinology, 91: 6 (1972).

29. Ko, H., and Royer, M.: A gas-liquid chromatographic assay for plasma free fatty acids. J. Chromatogr., 88: 253 (1974).

30. Lees, R. S., and Fredrickson, D. S.: Differentiation of exogenous and endogenous hyperlipidemia by paper electrophoresis. J. Clin. Invest., 44: 1968 (1965).
31. Lipid Research Clinics Program. Manual of Laboratory Operations. Department of Health, Education, and Welfare No. (NIH) 75-628, p. 51 (1974).

32. Macheboeuf, M., and Rebeyrotte. P.: Studies on lipoprotein cenapses of horse serum. Discussions Faraday Soc., 6: 62 (1949).

33. Mahley, R. W., and Innerarity, T. L.: Interaction of canine and swine lipoproteins with the low density lipoprotein receptor of fibroblasts as correlated with heparin/manganese precipitability. J. Biol. Chem., 252: 3980 (1977).

34. Mason, M. E., and Waller, G. R.: Dimethoxypropane induced transesterification of fats and oils in preparation of methyl esters for gas chromatographic analysis. Anal. Chem.. 36: 583 (1964).

35. Melichar, V., Novak, M., Hahn, P., Koldovsky, O., and Zeman, L.: Changes in the blood levels of lipid metabolites and glucose following a fatty meal in infants. Acta Paediatr., 51: 481 (1962).

36. Mills, G. L., and Taylaur, C. E.: The distribution and composition of serum lipoproteins in eighteen animals. Comp. Biochem. Physiol., 40B: 489 (1971).

37. Osborne, J. C., Jr., and Brewer, H. B., Jr.: The plasma lipoproteins. Adv. Protein Chem., 31: 253 (1977).

38. Ouchterlony. O.: Handbook of Immunodiffusion and Immunoelectrophoresis. p. 35 (Ann Arbor Science Publishers, Inc.. Ann Arbor, MI, 1968).

39. Parwaresch, M. R., and Radzun, H. J.: Lack of very low density lipoproteins in cord blood. Clin. Chim. Acta, 83: 295 (1978).

40. Persson, B., and Gentz. J.: The pattern of blood lipids, glycerol and ketone bodies during the neonatal period, infancy and childhood. Acta Paediatr. Scand. 55 353 (1966).

41. Quarfordt, S. H., Hilderman, H., Greenfield. M. R., and Shelburne, F. A.: The effect of human arginine rich apoprotein on rat adipose lipoprotein lipase. Biochem. Biophys. Res. Commun., 78: 302 (1977).

42. Rafstedt, S.: Studies on serum lipids and lipoproteins in infancy and childhood Acta Paediatr. Suppl., 102: 5 (1955).

43. Shore. V. G., Shore, B., and Hart. R. G.: Changes in apolipoproteins and properties of rabbit very low density lipoproteins on induction of cholesteremia Biochemistry, 13: 1579 (1974).

44. Singh, E. J., and Zuspan, F. P.: Amniotic fluid lipids in normal human pregnancy Am. J. Obstet. Gynecol.. 117: 919 (1973).

45. Solomon, S., Bird. C. E., Ling, W., Iwamiza, M., and Young, P. C. M.: Formation and metabolism of steroids in the fetus and placenta. Recent Prog. Horm. Res. 23: 297 (1967).

46. Soutar, A. K.. Garner, C. W., Baker, H. N., Sparrow, J. T., Jackson, R. L., Gotto A. M., and Smith, L. C.: Effect of the human plasma apolipoproteins and phosphatidyl acyldonor on the activity of lecithin:cholesterol acyltransferase Biochemistry, 14: 3057 (1975).

47. Srinivasan, S. R., McBride, J. R., Jr., Radhakrishnamurthy, B., and Berenson, G S.: Comparative studies on serum lipoprotein and lipid profiles in subhuman primates. Comp. Biochem. Physiol., 47B: 711 (1974).

48. Suenram, A., McConathy, W. J.. and Alaupovic, P.: Evidence for the lipoprotein heterogeneity of human plasma high density lipoproteins isolated by three different procedures. Lipids, 14: 505 (1979).

49. Tsang, R. C., Fallat, R. W., and Glueck, C. H.: Cholesterol at birth and age I: comparison of normal and hypercholesterolemic neonates. Pediatrics, 53:458 (1974)

50. Zee, P.: Lipid metabolism in the newborn. II. Neutral lipids. Pediatrics, 4I: 640 (1968)

51. Informed consent was not required by the Human Experimentation Committee University of Oklahoma Health Sciences Center, for this study because cord blood was considered to be a salvage product of delivery.

52. The authors acknowledge the technical assistance of Jerry Robinson. Jim Fesmire, Ruth Ballou. Tim Gross, and Shelly Slick, R.N. We also appreciate the advice and comments of Drs. P. Alaupovic, M. Curry, and P. Weech. This study would not have been possible without the assistance of Shirley Dorn, R.N., and the Staff of the Labor-Delivery Suite, Presbyterian Hospital, Oklahoma City.

53. Requests for reprints should be addressed to: Walter J. McConathy, Ph.D., Laboratory of Lipid and Lipoprotein Studies, Oklahoma Medical Research Foundation. 825 N. E. 13th Street, Oklahoma City, Oklahoma 73 :04 (USA).

54. This research was supported in part by the National Heart, Blood, and Lung Institute Contract N01-HV-2-2932L and United States Public Health Service Grant HL-23181.

55. Received for publication September 12, 1979

56. Accepted for publication January 2, 1980. 